\title{
Rancang Bangun Media Pembelajaran Augmented Reality Mengenal Alat Musik Degung
}

\author{
http://dx.doi.org/10.28932/jutisi.v6i2.2699
}

\author{
Yunita Agustin Mulyana ${ }^{\bowtie}$, Iwan Rizal Setiawan ${ }^{* 2}$, Lelah Lelah ${ }^{\# 3}$ \\ \#Jurusan Teknik Informatika, Universitas Muhammadiyah Sukabumi, Sukabumi, Jawa Barat \\ 1nagust in942@gmail.com \\ llelah@ummi.ac.id \\ 2myfrank@gmail.com
}

\begin{abstract}
Augmented Reality is one of information technology that still exists and being developed till now. This technology can show up a not real object in the real background. As we know, we can use technology to help our work and help us to make everything simple and easier. Nowadays, everything got easier and easier to do because of technology, it's because a lot of people try to make something useful to help them with their work. Therefore, this study uses one of the technologies, augmented reality, to introduce traditional musical instruments named Degung to all people who want to know about this instrument. They who want to show Degung to other but do not know an easy way, can use the result of this study using MDLC (multimedia development life cyle) method.
\end{abstract}

Keywords-Augmented Reality; MDLC Method; Technology.

\section{Pendahuluan}

\section{A. Latar Belakang}

Indonesia merupakan sebuah negara yang kaya akan budaya dan seni didalamnya. Salah satu yang terkenal dari Indonesia adalah alat musik tradisionalnya. Ada banyak sekali jenis alat musik tradisional di Indonesia mengingat banyak pula daerah - daerah yang ada di Indonesia, misalnya alat musik gambus dari riau, gamelan dari jawa tengah, bonang dari jawa timur, angklung dari jawa barat, dan masih banyak lagi alat musik dari daerah-daerah yang ada di Indonesia.

Di era globalisasi ini dampak negatif yang sangat terasa oleh bangsa Indonesia yaitu mulai tergesernya budaya tradisional, media dan teknologi yang canggih mempermudah akses masuk bagi budaya asing masuk ke Indonesia. Tapi selain dampak negatif yang dibawa oleh teknologi, tentu saja teknologi itu sendiri bisa dimanfaatkan untuk mempermudah bangsa Indonesia memperkenalkan budaya Indonesia dan melestarikan budaya Indonesia kepada semua orang dengan cara yang modern [1].

Jika melihat lagi apa alasan seni dan budaya di Indonesia mulai tergeser oleh budaya asing terlepas dari mulai masuknya budaya asing itu sendiri yaitu sulitnya menjumpai dan mempelajari seni itu sendiri. Jika kita melihat kearah seni musik, misalnya seseorang ingin belajar tentang alat musik tradisional, hal yang menghambat untuk mempelajarinya adalah alat musiknya itu sendiri karena alat musik tradisional tidak bisa dengan mudah didapatkan seperti alat musik pada umumnya seperti gitar, piano, dan alat musik klasik lainnya, disinilah peran teknologi sangat dibutuhkan [2].

Kembali lagi membahas tentang seni dan budaya, ada banyak sekali seni dan budaya di Indonesia, dan yang akan dibahas disini adalah alat musik degung yang berasal dari jawa barat. Degung atau degungan adalah sekumpulan alat musik yang terdiri dari beberapa alat musik diantaranya bonang, saron, jengglong, suling, kendang, dan juga gong. Alat musik ini dimainkan bersamaan untuk menghasilkan sebuah musik yang diinginkan. Degungan ini berasal dari jawa barat, biasanya alat musik degung ini dimainkan untuk mengiringi pertunjukan wayang atau tari-tarian seperti jaipong [3].

Sulitnya menjumpai alat musik degung dan mahalnya harga alat degung itu sendiri menjadi masalsah tersendiri untuk mereka yang ingin mempelajari alat musik degung ini, maka dari itu disinilah munculnya peran teknologi untuk membantu mereka yang ingin mempelajari tentang alat musik degung.

Tujuan penelitian ini adalah mengetahui seberapa besar minat masyarakat di Indonesia dalam melestarikan alat musik tradisional yaitu alat musik Degung lalu membuat sebuah media pembelajaran berbasis augmented reality untuk mengenal alat musik Degung yang berasal dari Jawa Barat yang bertujuan untuk mempermudah mereka yang ingin belajar atau mengetahui secara dasar tentang alat musik Degung itu sendiri. Aplikasi ini dikhususkan untuk pengguna smartphone Android.

Adapun mafaat dari aplikasi ini nantinya yaitu untuk mempermudah mereka yang ingin belajar alat musik degung yang sejatinya sulit ditemukan dibanyak tempat. Selain itu aplikasi ini juga dibuat untuk mempermudah mereka yang 
ingin mengenalkan alat musik Degung ke masyarakat lain yang belum mengetahui sama sekali tentang alat musik ini.

\section{STUDI PUSTAKA}

\section{A. Augmented Reality}

Dalam penelitiannya, Zwingly Ch Rawis, Virgiana Tulenan, dan Brave A. Sugiarso yang berjudul "Penerapan Augmented Reality Berbasis Android Untuk Mengenalkan Pakaian Adat Tountemboan" [4] mereka memanfaatkan teknologi augmented reality untuk memperkenalkan pakaian adat. Dalam pembuatan aplikasinya, mereka menggunakan teknik markerless yaitu tanpa marker. Seperti yang diketahui ada beberapa teknik dalam augmented reality diantaranya Marker Based Tracking yang menggunakan marker dalam peroperasiannya dan Markerless Based Tracking yang tidak menggunakan marker dalam pengoperasiannya. Untuk markerless sendiri terdiri lagi dari beberapa bagian yaitu motion tracking, face tracking, GPS based tracking, dan $3 D$ object tracking.

Adapun dalam penelitiannya yang berjudul "Pemanfaatan Augmented Reality Untuk Pembelajaran Pengenalan Alat Musik Piano" [5], Iwan Stya Nugraha, Kodrat Iman Satoto, dan Kurniawan Teguh Martono menggunakan teknologi augmented reality untuk memperkenalkan alat musik piano. Dalam aplikasinya, mereka menampilkan bentuk piano itu sendiri dan juga cara memainkannya. Berbeda dengan penelitian Zwingly Ch Rawis, Virgiana Tulenan, dan Brave A. Sugiarso yang tidak menggunakan marker dalam penelitiannya, Iwan Stya Nugraha, Kodrat Iman Satoto, dan Kurniawan Teguh Martono menggunakan marker sebagai acuan tampilnya alat musik piano.

Dalam pemanfaatannya, augmented reality sendiri digunakan untuk memunculkan objek yang tidak nyata kedalam lingkungan nyata secara real-time. Umtuk kasus diatas, objek yang ditampilkan berbentuk 3 dimensi yang dipadukan dengan 2 dimensi sebagai pelengkap misalnya menampilkan info. Untuk penggunaannya, augmented reality wajib menggunakan kamera perangkat yang mengoperasikannya karena camera adalah perantara antara pengguna dan objek yang ditampilkan [6].

Untuk contoh sederhana pemanfaatan teknologi augmented reality yang bisa dibilang umum dimasyarakat yaitu games Pokemon Go yang sempat booming di tahun 2016-2017. Games ini mengusung tema pokemon yang bias ditemukan di wilayah tertentu. Untuk Pokemon Go ini mereka menggunakan teknik GPS Based Tracking yaitu memanfaatjan fiture GPS yang terintegrasi dengan maps [7].

\section{B. MDLC (Multimedia Development Life Cycle)}

MDLC atau Multimedia Development Life Cycle adalah sebuah adalah sebuah metode yang biasanya digunakan untuk mengembangkan sebuah aplikasi yang berbentuk media seperti media pembelajaran, games, dan Augmented Reality [4].

MDLC memiliki 6 tahapan dalam pelaksaannya, diantaranya adalah:

\section{Concept (Konsep)}

Tahap ini adalah tahap awal dalam pembuatan program yang akan dibuat, dalam tahap ini ditentukan fungsi dari program dan untuk siapa program ini ditujukan.

\section{Design (Desain)}

Tahap ini adalah tahap merancang interface atau tampilan program yang akan dibuat, tampilan akan disesuaikan dengan kebutuhan dan mengacu kepada konsep yang telah ditentukan sebelumnya.

\section{Material Collection (Pengumpulan bahan)}

Tahap ini adalah tahap pengumpulan bahan bahan yang akan digunakan untuk membangun program yang akan dibuat misalnya foto, video, gambar, suara dan material penunjang lainnya. Bahan - bahan ini bisa didapatkan di-website yang sudah tersedia, untuk material foto, video dan media lainnya biasanya ada yang gratis dan ada pula yang berbayar. Selain itu juga kita bisa mendapatakan material yang kita butuhkan dengan membuatnya sendiri [8].

4, Assembly (Pembuatan)

Tahap ini adalah tahap menggabungkan sebuah material yang ada berdasarkan dengan rancangan yang sudah dibuat hingga menghasilkan sebuah program yang diinginkan dan sesuai dengan apa yang sudah dirancang sebelumnya.

5. Testing (Pengujian)

Tahap dimana program atau aplikasi yang ada diuji untuk dilihat apakah sudah sesuai dengan yang diinginkan atau belum. Lalu dilihat juga apakah ada kekurangan pada program ini atau tidak. Tahap ini bisa dilakukan berulang kali untuk mencapai hasil yang diinginkan [3].

\section{Distribution (Distribusi)}

Tahap terakhir pada MDCL, ditahap ini aplikasi yang sudah jadi akan disimpan disebuah media penyimpanan atau didistribusikan untuk keperluan tertentu [4].

\section{Android}

Dalam penelitiannya, Zwingly Ch Rawis, Virgiana Tulenan, dan Brave A. Sugiarso yang berjudul "Penerapan Augmented Reality Berbasis Android Untuk Mengenalkan Pakaian Adat Tountemboan" [4] mereka menggunakan flatform android untuk aplikasi augmented reality mereka. Dalam kebijakan privasinya, biasanya platform android meminta izin 
untuk pengaksesan kamera dan penyimpanan. Versi android yang digunakan pun tidak dipatok rata tapi dipatok sesuai kebutuhan [9].

\section{A. Alat Musik Degung}

Degung atau Degungan adalah sekumpulan alat musik tradisional asal Jawa Barat yang dimainkan secara bersamaan hingga membentuk sebuah melodi. Adapun 7 wadirta wajib dalam Degung [10], yaitu :

1. Bonang

Bonang adalah sebuah alat musik yang terdiri dari 14 penclon yang berfungsi sebagai pembawa melodi. Boning sendiri terbuat dari perunggu dan cara memainkannya adalah dipukul dengan alat pemukul khusus.

2. Jengglong

Sebuah alat musik yang terdiri dari 6 penclon penclon ini berbentuk seperti gong dan jengglong biasanya digantung. Jengglong sendiri terbuat dari kuningan atau besi. Jengglong ini berfungsi sebagai penegas melodi bonang.

3. Saron Panerus

Saron panerus memiliki bentuk yang sama persis dengan saron peking. Yang membedakan adalah nadanya. Nada terendah dari Saron panerus adalah La yang terendah dan Mi yang tertinggi. Fungsinya dalam degung adalah pelengkap nada peking dan juga patokan nada bonang.

4. Saron Cempres/Peking

Sebuah alat musik yang terdiri dari 1214 wilah nada dasarnya adalah mi yaitu nada tertinggi dan la nada terendah untuk yang 14 wilah. Fungsinya dalam degung adalah lilitan melodi. Saron ini terbuat dari bahan logam perunggu dan cara memainkannya adalh dipukul menggunakan pemukul khusus berbentuk palu.

5. Kendang

Kendang ini adalah sebuah alat musik yang dimainkan dengan cara ditepuk-tepuk. Kendang terbuat dari kulit sama halnya dengan bedug. Fungsi kendang dalam degung adalah mengatur irama lagu.

6. Suling

Sebuah benda panjang berbentuk tabung yang memiliki 6 buah lubang, terbuat dari bambu. Cara memainkannya adalah dengan cara ditiup sembari jari-jari menutup dan membuka lobangnya satu persatu hingga menghasilkan nada yang diinginkan. Dalam degung, alat ini berfungsi sebagai lilitan melodi atau pembawa melodi.

\section{Gong}

Sebuah alat musik yang berfugsi sebagai penutup diakhir kalimat lagu. Cara memainkannya adalah dipukul. Gong ini adalah alat musik yang berbentk bulat dan besar dan tentu saja nadanya paling rendah daripada yang lain.

\section{Metode Penelitian}

\section{A. Teknik Pengumpulan Data}

\section{Wawancara}

Peneliti mewawancara salah satu mahasiswa untuk mendapatkan data terkait penelitian. Data yang ingin diperoleh untuk penelitian ini adalah tentang seberapa besar minat narasumber untuk mengenal alat musik degung dan apa masalah yang dihadapi saat ingin memulai mengenal alat musik tersebut.

Berikut adalah hasil wawancara yang telah dilakukan dengan narasumber yaitu seorang mahasiswa :

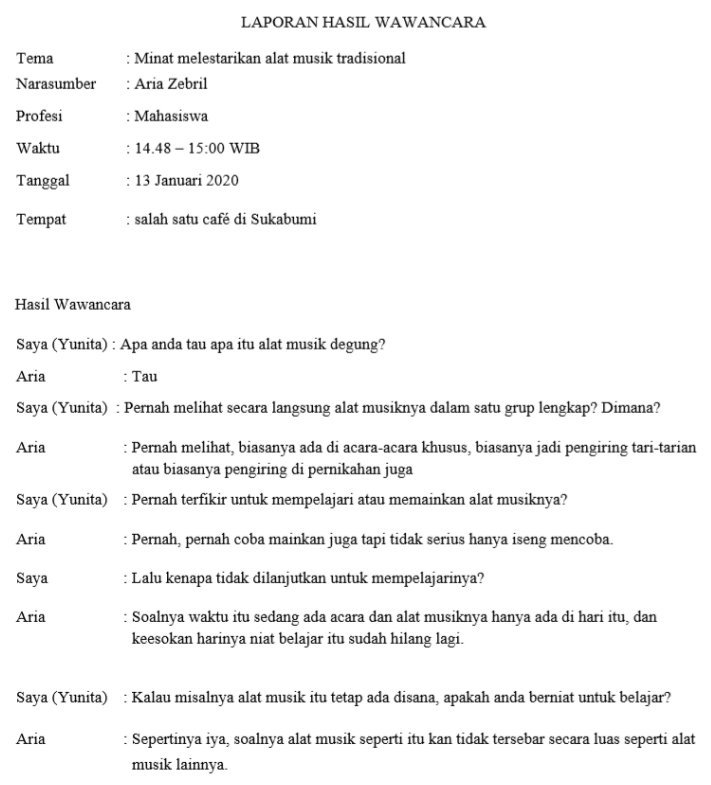

Gambar 1. Ini adalah hasil wawancara narasumber dengan peneliti yang menghasilkan sebuah informasi bahwa minat anak muda untuk mengenal lebih dalam tentang alat musik degung itu ada namun sedikit terhambat dengan tidak mudahnya didapatkan alat musik tersebut.

Gambar 1 menunjukkan hasil wawancara yang sudah dilakukan terhadap narasumber dan hasilnya didapatkanlah fakta bahwa sebenarnya minat untuk mengenal alat musik itu ada, namun terbatasnya alat musik menghambat mereka yang ingin mempelajari alat musik degung tersebut.

\section{Kuesioner}

Peneliti menyebarkan kuisioner untuk mendapatkan data tambahan yang digunakan untuk 
melengkapi perangkat penelitian, penyebaran kuisioner dilakukan dengan menggunakan google form. Pada gambar 2 memuat gambar yang berisi data tentang umur responden yang mengisi kuesioner, gambar 3 adalah gambar diagram yang memuat data tentang pengetahuan responden tentang alat musik degung, untuk gambar 4 memuat data diagram tentang minat responden mengenal alat musik degung, dan gambar 5 memuat data tentang minat responden menggunakan aplikasi yang akan dibuat nantinya.

\section{Umur \\ 94 tanggapan}

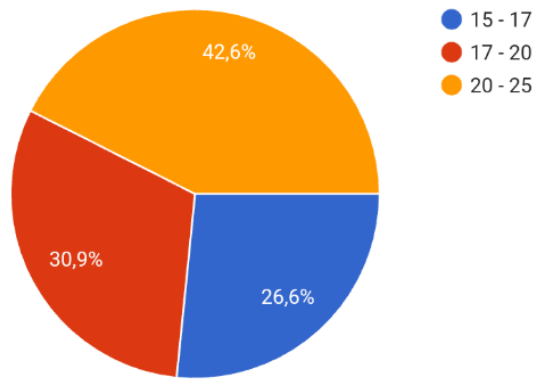

Gambar 2. Diagram ini memberikan informasi tentang umur responden.

Responden yang mengisi kuisioner ini adalah para remaja hingga orang dewasa dengan maksimal umur 25 tahun.

Pernah dengar tentang alat musik degung?

94 tanggapan

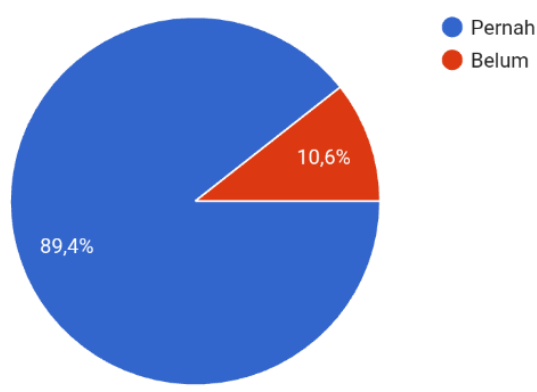

Gambar 3. Diagram ini memberikan informasi mengenai apakah responden mengetahui alat musik degung atau tidak sama sekali.

Diagram ini menunjukan bahwa $89,4 \%$ responden mengetahui tentang alat musik ini, dan sisanya $10,6 \%$ benar-benar tidak tahu.

\section{Saat melihat alat musik degung, apakah anda pernah tertarik untuk memainkannya?}

94 tanggapan

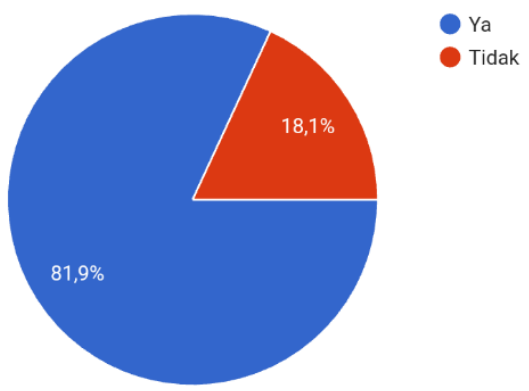

Gambar 4. Diagram ini memberikan informasi mengenai minat responden untuk memainkan alat musik degung.

Diagram ini menunjukan bahwa $81,9 \%$ responden tertarik untuk mencoba memainkan alat musik degung, dan sisanya $18,1 \%$ berkata tidak.
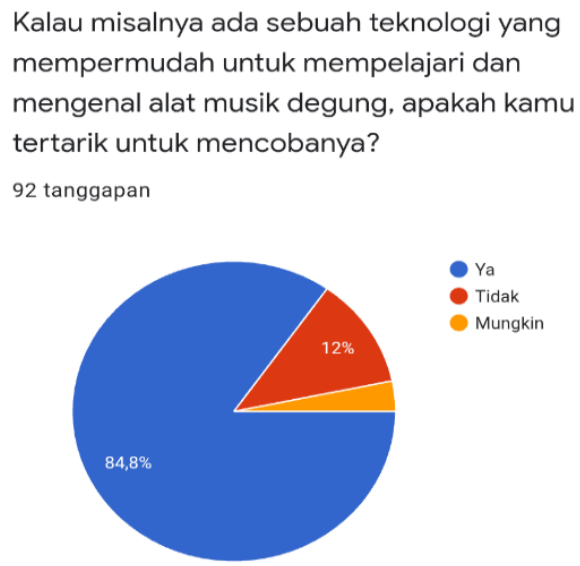

Gambar 5. Diagram ini memberikan informasi mengenai minat responden untuk memainkan alat musik degung jika ada aplikasi yang mempermudah mereka.

Diagram ini menunjukan bahwa $84,8 \%$ responden tertarik untuk mencoba memainkan alat musik degung jika ada aplikasi yang mempermudah mereka untuk mempelajari itu, dan sisanya $12 \%$ berkata tidak terarik.

3. Studi Pustaka

Peneliti mencari informasi dan data dari sumbersumber yang ada seperti buku atau jurnal.

B. Perangkat yang digunakan

1. Perangkat keras yang digunakan untuk penelitian
a. Tipe
$\therefore$ Personal Computer
b. Tipe $O S$
: Windows 10
c. $R A M$
: $8 \mathrm{~GB}$
d. Storage
$: 1 \mathrm{~TB}$
e. Monitor
: 14.5 inch 
2. Perangkat lunak yang digunakan sebagai berikut :
a. Unity 2017
b. Vuforia
c. Vegas Pro 16
d. Audacity
e. Photoshop CS6
f. Blender 3D

3. Perangkat yang disarankan untuk menjalankan aplikasi :
a. OS : Android
b. RAM : $2 \mathrm{~GB}$
c. Storage : 8GB
d. Processor : Snapdragon 400

C. Flowchart Alur Sistem

Flowchart menggambarkan alur sistem dari aplikasi yang akan dibuat. Flowchart alur sistem augmented reality digambarkan dalam gambar 6.

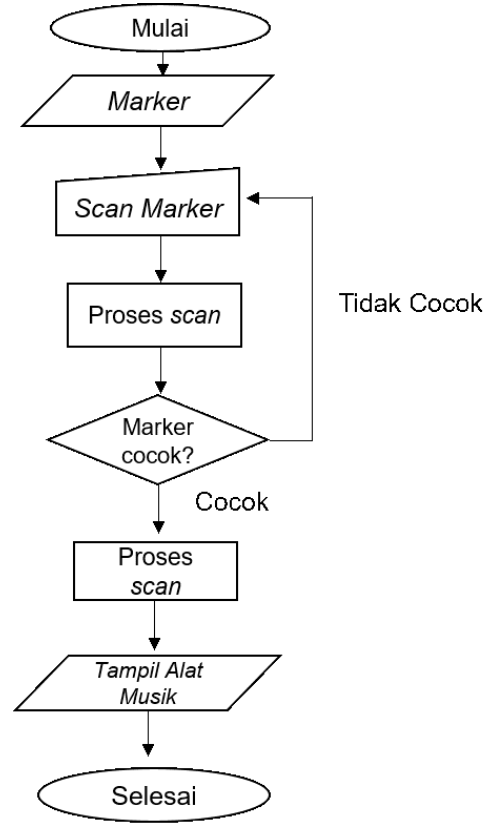

Gambar 6. Ini adalah Flowchart Alur Sistem Augmented Reality

\section{Struktur Menu}

Dalam struktur menu, bagian-bagian menu diperlihatkan secara lebih detail. Struktur menu memperlihatkan komponen-komponen yang ada didalam sebuah aplikasi yang akan dibuat. Struktur menu digambarkan dalam gambar 7 .

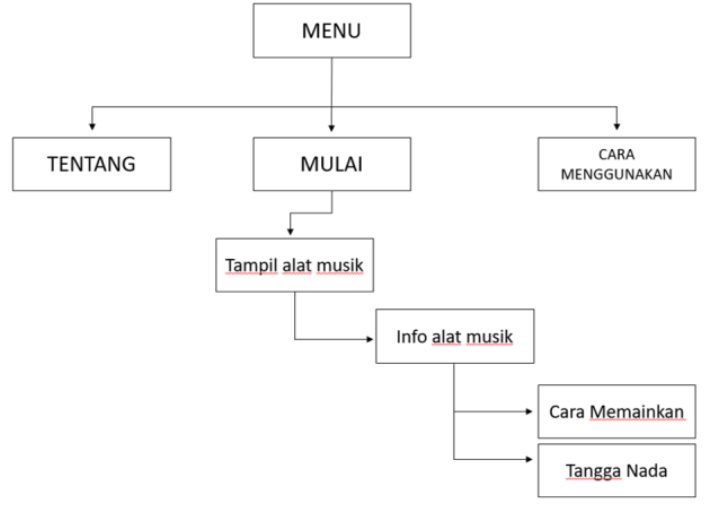

Gambar 7. Ini adalah gambar striktur menu dari aplikasi yang akan dibuat

\section{HASIL PEMBAHASAN}

Pada pembahasan ini aplikasi telah dibuat menggunakan tahap-tahap metode MDLC (Multimedia Develpoment life cycle), dan hasilnya akan diperlihatkan satu-persatu.

1. Konsep

Aplikasi yang dibuat ini didalamnya terdiri dari objek 3D dari alat musik Degung Jawa Barat, dan tombol menu yang terdiri dari info alat musik yang ditampilkan dari mulai bahan, cara memainkan, dan fungsinya dalam Degungan. Alur dari aplikasi yang dibuat ini yang pertama adalah pengguna harus menyiapkan kartu yang bergambar alat musik yang sudah disediakan, setelah kartu disediakan pengguna mulai memindai kartu yang ada hingga alat musik muncul, munculnya alat musik berdasarkan kartu yang dipindai, jika pengguna memindai kartu kendang maka objek yang akan tampil adalah kendang. Didalam aplikasi ini pengguna juga bisa memainkan alat musik yang ada dengan cara menekan alat musik didalam layar hingga berbunyi. Bunyi alat musik akan menyesuaikan dengan nada alat musik yang asli dengan kemiripan sekitar $80 \%$. Untuk tampilannya, alat musik yang ditampilkan nantinya bisa diputar $180^{\circ}$ dengan cara memutar ponsel atau memutar kartu. Sisi alat musik yang bisa dilihat adalah, sisi atas dan sisi samping. Untuk bagian kartu yang dipindai adalah bagian atas kartu.

a. Spesifikasi Perangkat Keras

Dan berikut ini adalah spesifikasi minimum perangkat keras yang harus disediakan oleh pengguna saat ingin menggunakan aplikasi ini yang akan dijelaskan dalam tabel I.

TABEL I

SPESIFIKASI MiNIMUM PENGGUNA

\begin{tabular}{|l|l|}
\hline Android & 6.1 Marshmallow \\
\hline RAM & 1 GB \\
\hline Prosesor & Snapdragon 400 \\
\hline Storage & Free 2 GB \\
\hline
\end{tabular}


2. Desain

Setelah merancang struktur menu, selanjutnya adalah merancang tapilan yang akan digunakan dalam aplikasi yang akan dibuat nantinya. Perancangan menu utama digambarkan dalam gambar 8 yang didalamnya terdapat beberapa menu yang dapat digunakan oleh pengguna. Dan pada gambar 9 dan gambar 10 terdapat tampilan tentang aplikasi dan juga cara menggunakan yang muncul saat pengguna menekan tombol tentang atau cara menggunakan. Pada gambar 11 dan gambar 12 menunjukan rancangan tampilan AR Camera yang muncul saat pengguna menekan tombol Mulai.

1. Perancangan Tampilan Main Menu

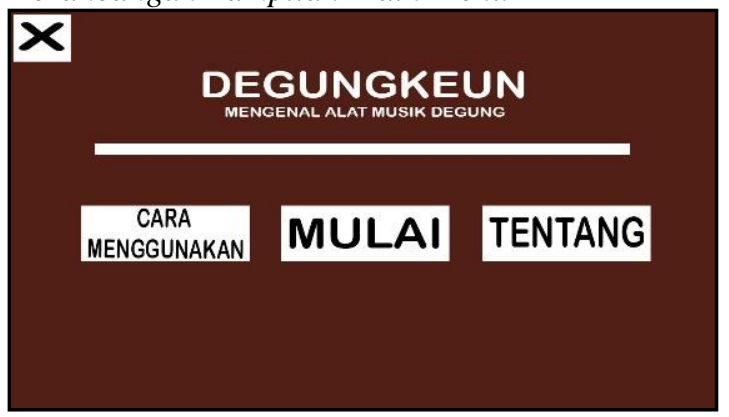

Gambar 8. Perancangan Tampilan Main Menu

2. Perancangan Tampilan Tentang Aplikasi

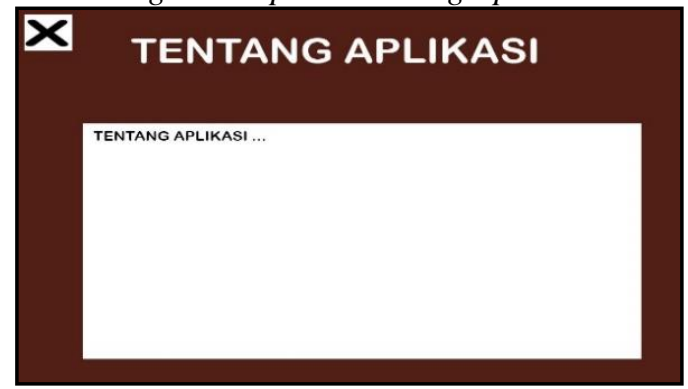

Gambar 9. Perancangan Tampilan Tentang Aplikasi

3. Perancangan Tampilan Cara Menggunakan

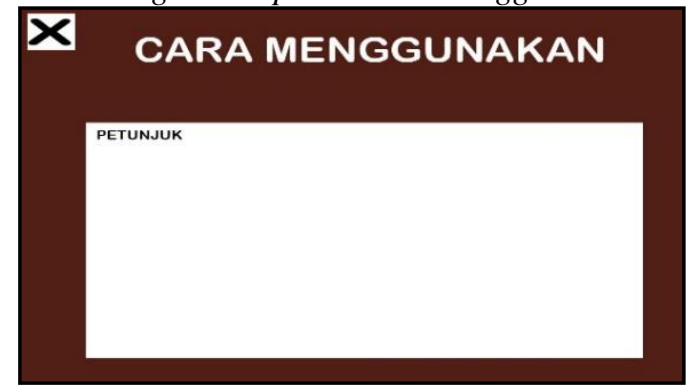

Gambar 10. Perancangan Tampilan Cara Menggunakan

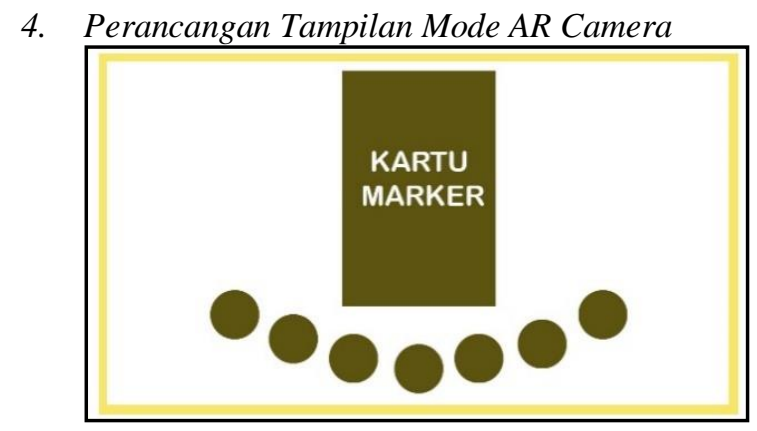

Gambar 11. Perancangan Tampilan mode AR Camera

5. Perancangan Tampilan Objek 3D Muncul

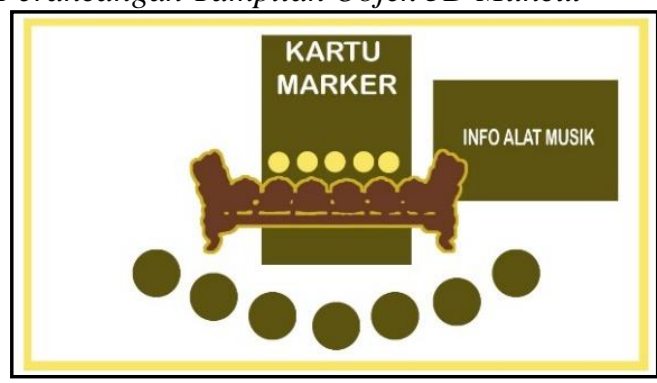

Gambar 12. Perancangan Tampilan Objek 3D Muncul

b. Storyboard

Storyboard digunakan untuk merancang alur dari aplikasi yang akan dibuat. Storyboard aplikasi ini dijelaskan dalam gambar 13[11]. 


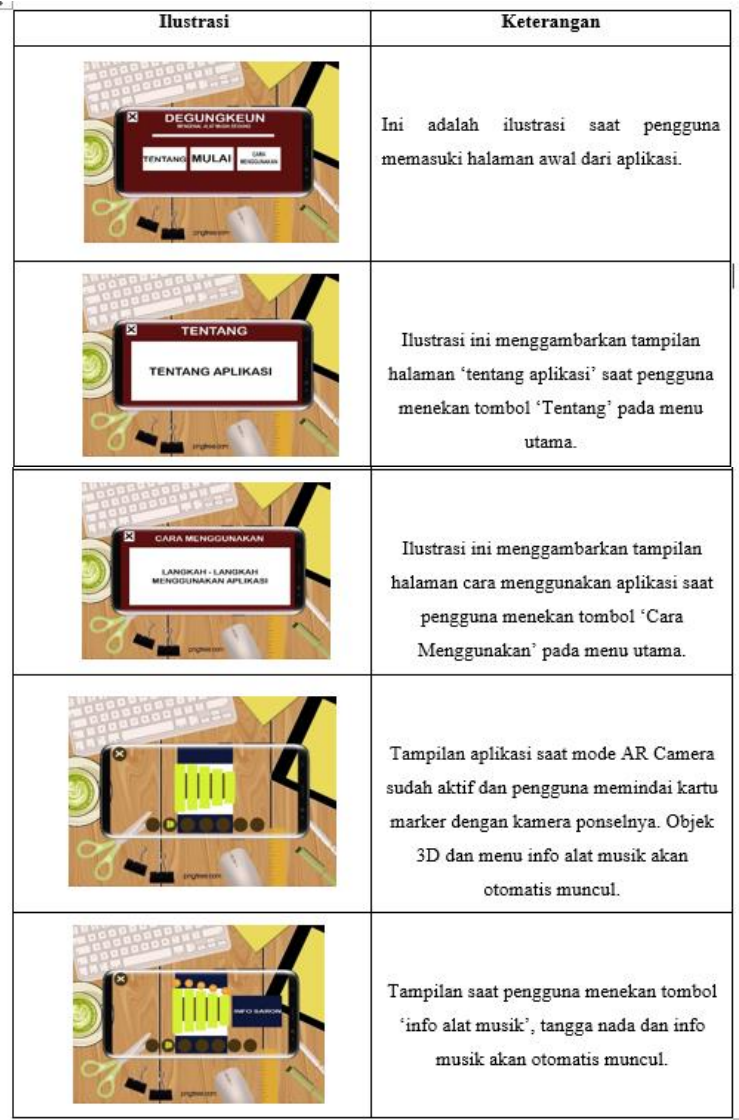

Gambar 13. Storyboard aplikasi

\section{Material Collection (Pengumpulan Bahan)}

1. Objek 3D

3D objek yang sudah dibuat adalah hal yang paling inti dalam aplikasi ini, alat musik ini nantinya akan muncul pada saat pengguna aplikasi mengarahkan kamera ponselnya kepada marker yang sudah disediakan. Alat musik yang akan muncul sesuai dengan marker yang sudah ditentukan, setiap marker memiliki perbadaan masing-masing. Informasi tentang alat musik 3D yang akan digunakan dalam pembuatan aplikasi akan dijelaskan pada Tabel II.

TABEL III

OBJek 3D Alat Musik Degung

\begin{tabular}{|l|l|}
\hline Objek & Keterangan \\
\hline & $\begin{array}{l}\text { Objek 3D alat musik } \\
\text { Bonang }\end{array}$ \\
\hline
\end{tabular}

\begin{tabular}{|l|l|}
\hline Objek 3D alat musik \\
Gong
\end{tabular} \mid $\begin{aligned} & \text { Objek 3D alat musik } \\
& \text { Jengglong }\end{aligned}$

2. Marker

Marker adalah sebuah alas dimana nantinya objek 3D akan muncul, setiap objek 3D memiliki marker yang berbeda dan marker pun dibuat berbeda satu sama lain. Jumlah marker disesuaikan dengan jumlah alat musik 3D yaitu 7 buah. Ukuran dari markernya sendiri adalah $5 \mathrm{~cm} \times 8 \mathrm{~cm}$ dan berbentuk 2D. Semua marker ditunjukan dalam tabel III. 


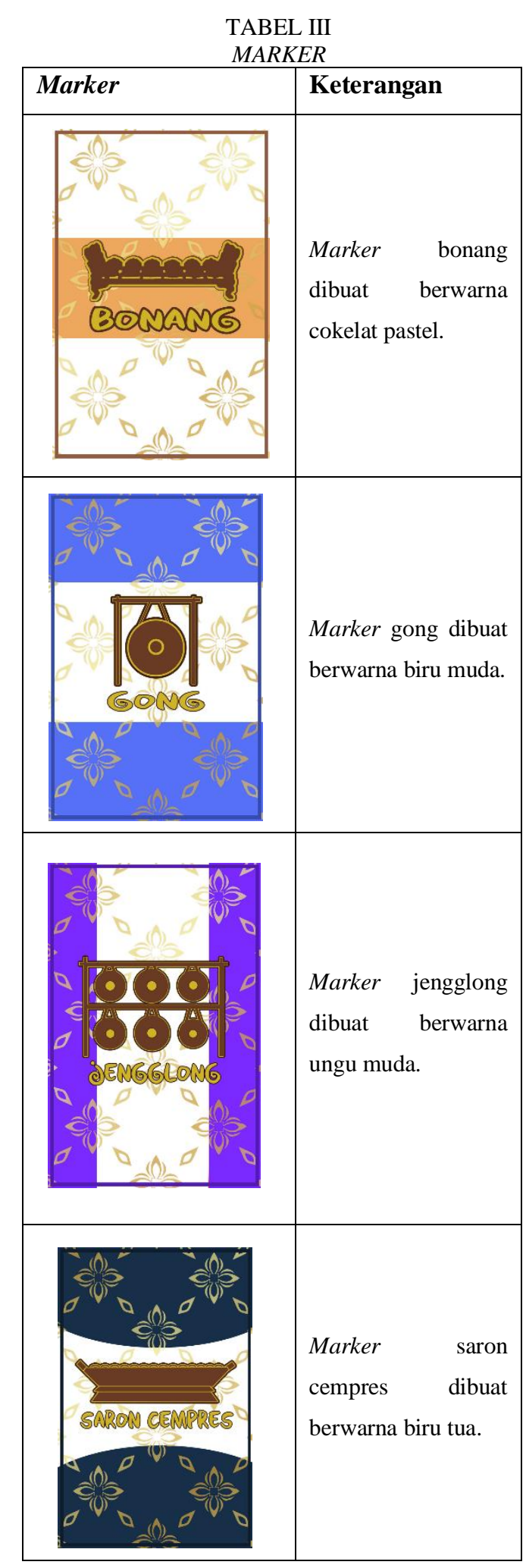

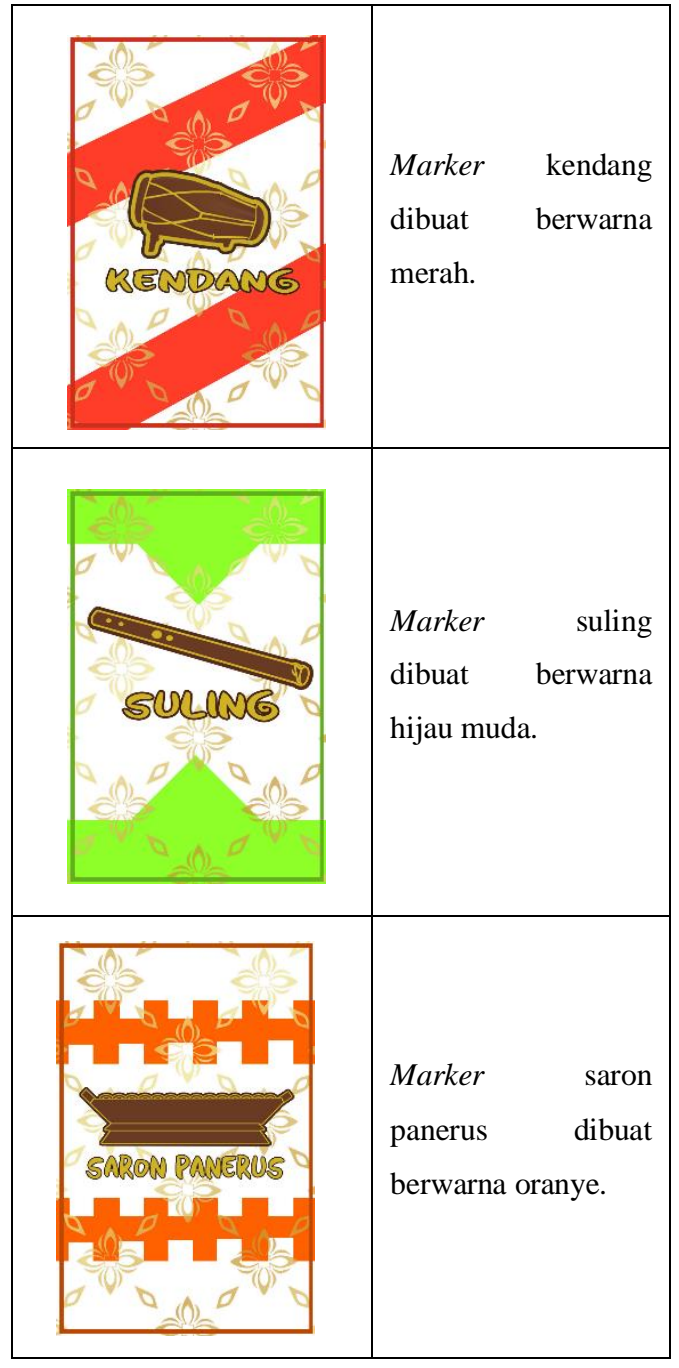

\section{Assembly (Pembuatan)}

Tahapan pembuatan ini dimulai dengan membuat sebuah marker dengan menggunakan sebuah software yang dikhususkan untuk membuat sebuah game yaitu software unity dan juga vuforia, dimana aplikasi ini bisa membuat marker untuk Augmented Reality.

a. Pembuatan Lisensi

Di sebuah web bernama Vuforia. Vuforia ini sudah bisa langsung dihubungkan dengan aplikasi utama yaitu Unity. Untuk pembuatannya pengguna Vuforia diharuskan Log in terlebih dahulu, penggunaan Vuforia ini tidak dipungut biaya sepeserpun. Tampilan halaman lisensi vuforia ditampilkan dalam gambar 14. 


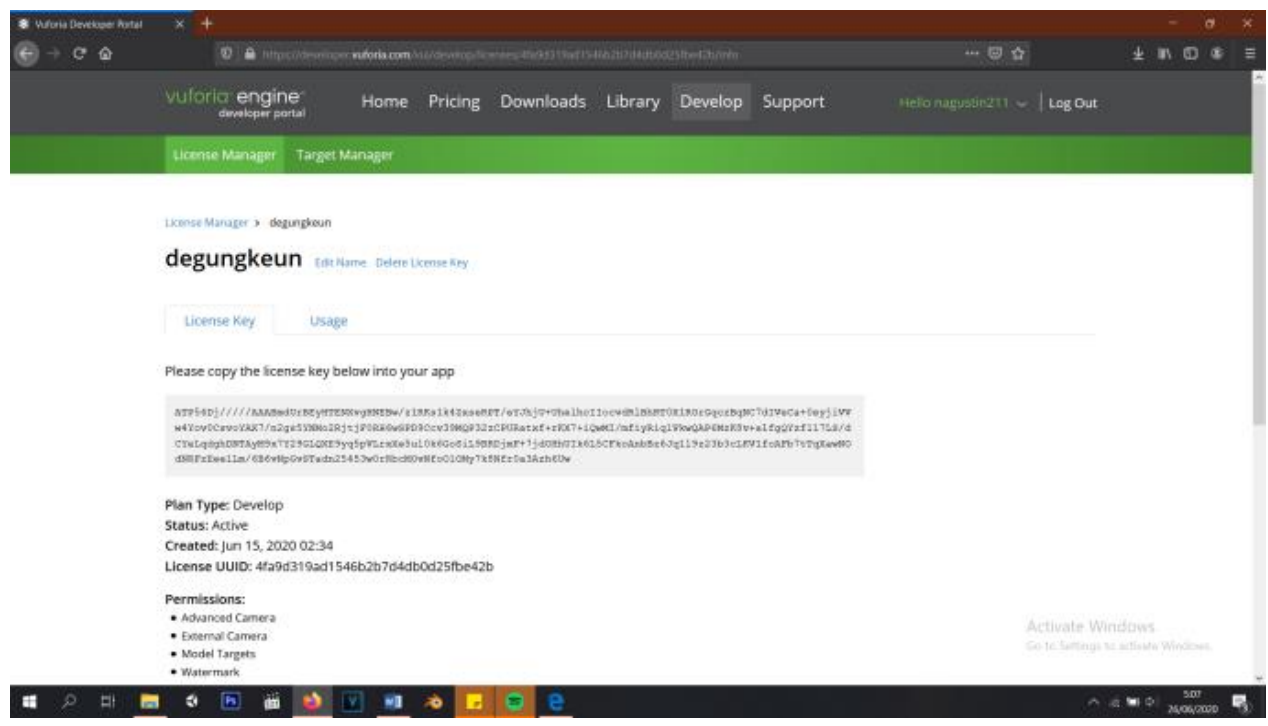

Gambar 14. Pembuatan Lisensi

Setelah mendapatkan lisensi, selanjutnya adalah pembuatan marker. Untuk pembuatan marker sendiri masih menggunakan laman vuforia ini, disana akan ada pilihan target manager, pengguna tinggal membuat basis data baru lalu mengunggah desain marker yang sudah dibuat. Untuk lebih mempermudah pengguna dalam penggunaannya, penamaan basis data marker bisa disamakan dengan nama lisensi.

b. Proses menyesuaikan alat musik

Proses ini adalah proses dimana alat musik 3D yang sudah disediakan akan disesuaikan dengan marker yang sudah ada. Total ada 7 alat musik dengan 7 marker yang berbeda.

Penyesuaian alat musik ini nantinya akan berpengaruh terhadap munculnya alat musik diatas marker. Cara kerja aplikasi Augmented reality ini adalah menggunakan computer vision atau bidang ilmiah yang membahas bagaimana komputer dapat memiliki kemampuan pemahaman tingkat tinggi dari gambar atau bisa dibilang computer vision ini bertugas melakukan pekerjaan yang biasa dilakukan oleh visual manusia secara otomatis, dan cara kerjanya adalah dengan mendeteksi citra dan citra yang digunakan disini adalah marker yang sudah disediakan. Disaat kamera diarahkan kepada marker, setelah itu computer vision akan menganalisis marker dan melihat apakah marker ini cocok seperti yang ada pada database atau tidak, jika cocok, sistem akan memanggil objek 3D dan memunculkannya di layar ponsel, dan jika tidak, sistem tidak akan bereaksi apa-apa dan gambar pun tidak akan muncul.

Proses menyatukan alat musik 3D dengan marker yang sudah disediakan sebelumnya diperlihatkan dalam gambar 15 .

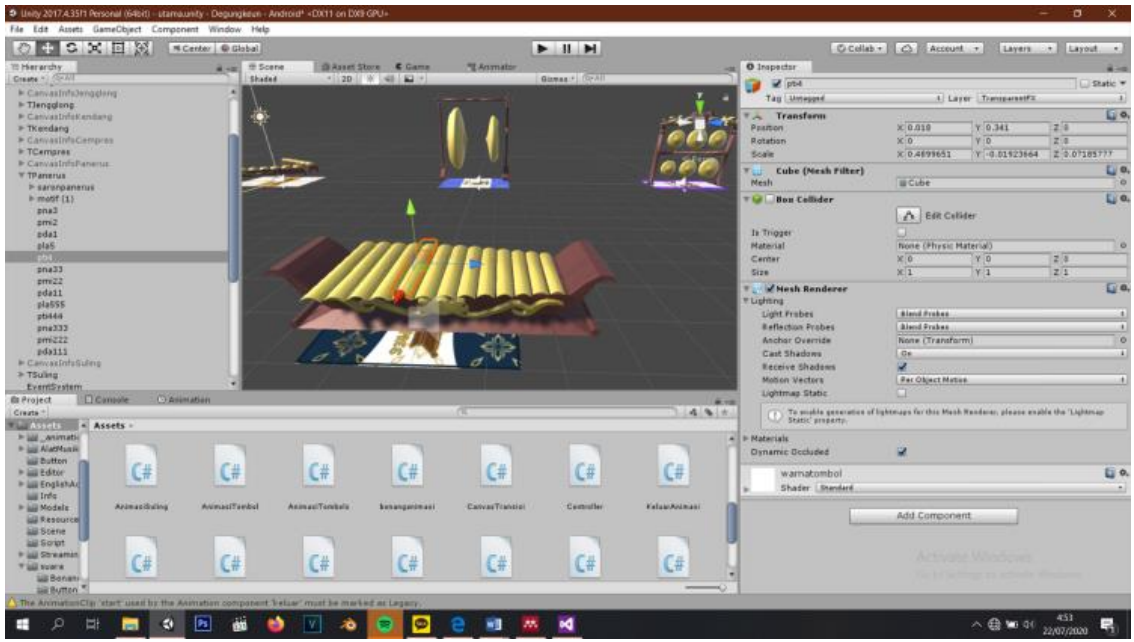

Gambar 15. Penggabungan alat musik dan marker 
a. Memasukan suara pada masing-masing alat musik

Masing-masing alat musik memiliki suara yang berbeda-beda. 1 alat musik bisa menghasilkan $2-14$ suara yang berbeda-beda nadanya. Ada total 56 suara yang harus disesuaikan dengan masing-masing alat musik yang ada. Gambar 16 dan 17 menunjukkan cara menghasilkan suara pada setiap alat musik degung.

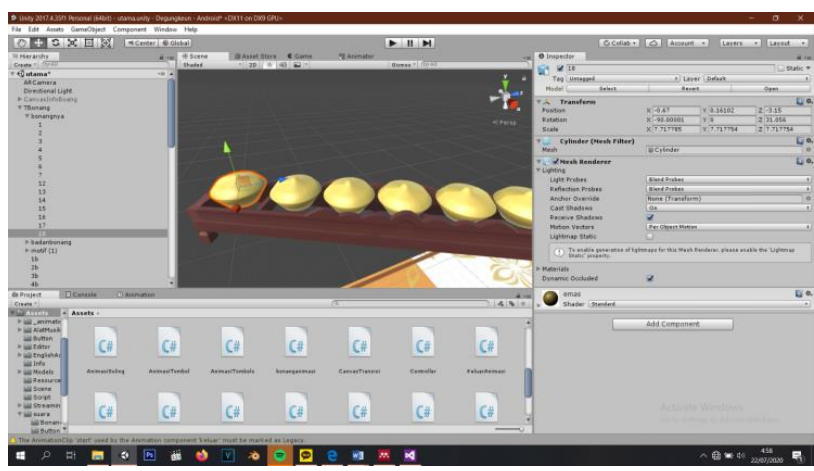

Gambar 16. Mengubah objek menjadi tombol dan memasukan suara

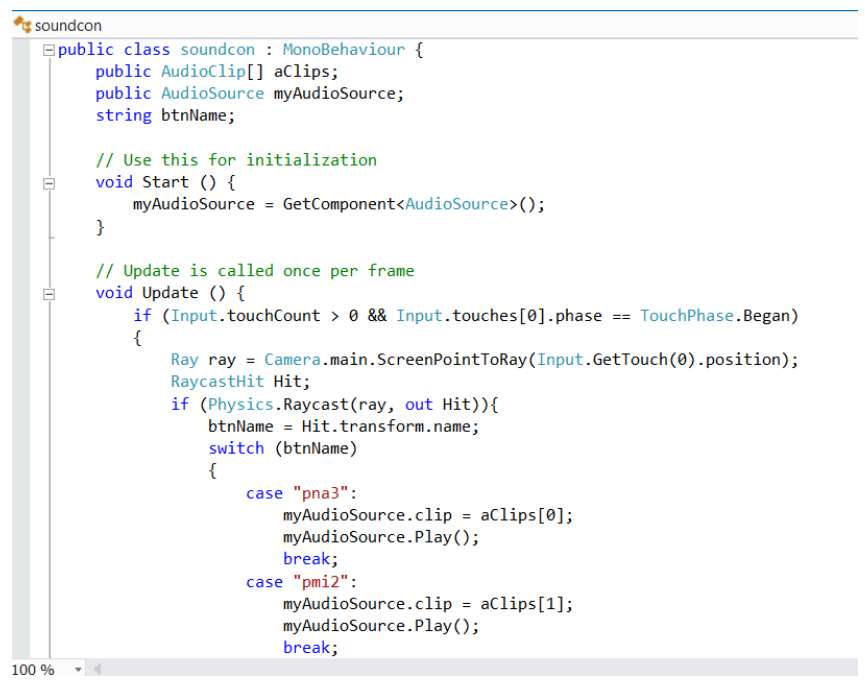

Gambar 17. Cuplikan kode yang digunakan untuk memunculkan suara setiap alat musik yang ada.

\section{Testing (Pengujian)}

Dalam melakukan tahap pengujian, tahapan ini dikhususkan dan dilakukan oleh para pelajar ataupun pengguna lain yang bisa menilai dan memberikan masukan terhadap aplikasi yang kita rancang juga kekurangan yang terdapat didalam aplikasi agar nantinya bisa dimasukan kedalam aplikasi pembelajaran ini. Pengujian akan dilakukan juga dengan menggunakan Blackbox. Gambar 18 sampai 23 menampilkan gambar hasil tangkapan layar saat aplikasi digunakan.

1. Tampilan Main Menu

Ada 3 tombol utama dalam halaman menu ini yaitu

'Mulai' yang befungsi sebagai tombol utama yang mengarah langsung ke mode AR Camera, tombol 'cara menggunakan' yang akan menampilkan halaman tata cara penggunaan aplikasi, dan yang terakhir tombol 'tentang' yang akan menampilkan informasi tentang aplikasi.

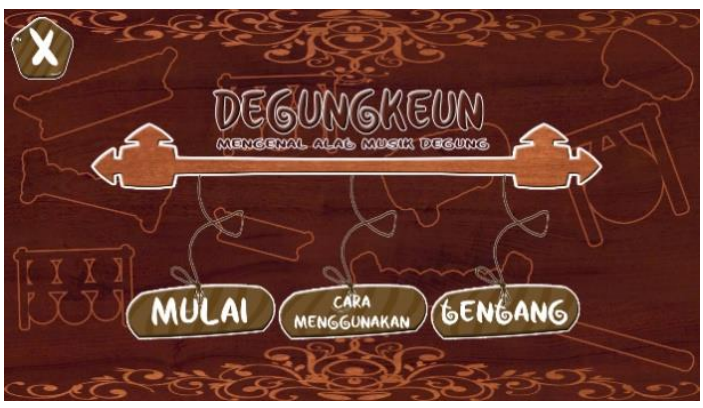

Gambar 18. Tampilan Main Menu

\section{Tampilan Cara Menggunakan}

Ini adalah isi dari halaman tombol 'Cara Menggunakan, halaman ini berisi 3 bagian yang akan muncul secara bergantian.

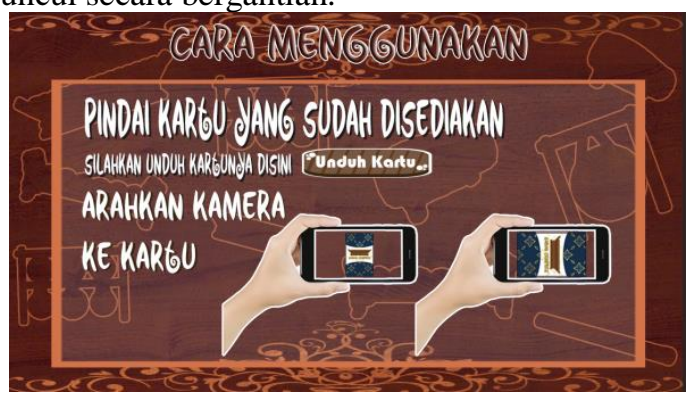

Gambar 19. Tampilan Cara Menggunakan

3. Tampilan Tampil Alat Musik Kendang

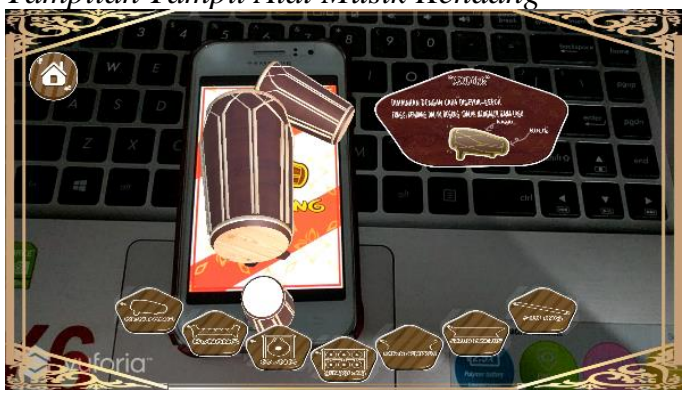

Gambar 20. Hasil tampilan pemilihan level 
4. Tampilan Alat Musik Jengglong

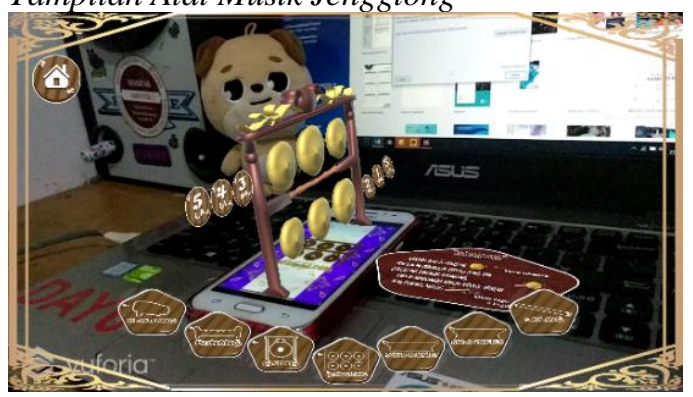

Gambar 21. Hasil tampilan alat musik jengglong

5. Tampilan Alat Musik Bonang

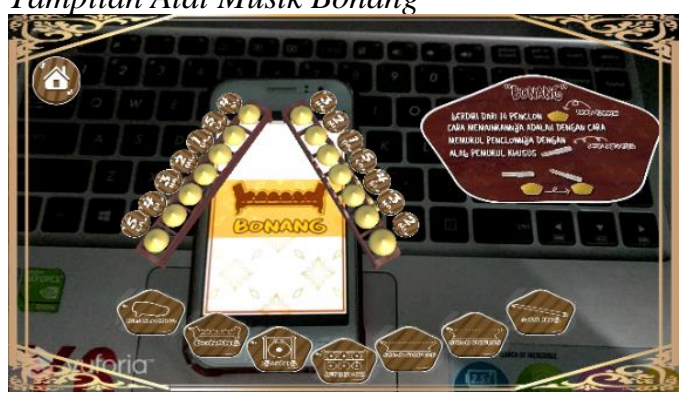

Gambar 22. Hasil tampilan alat musik bonang

\section{Tampilan Alat Musik Gong}

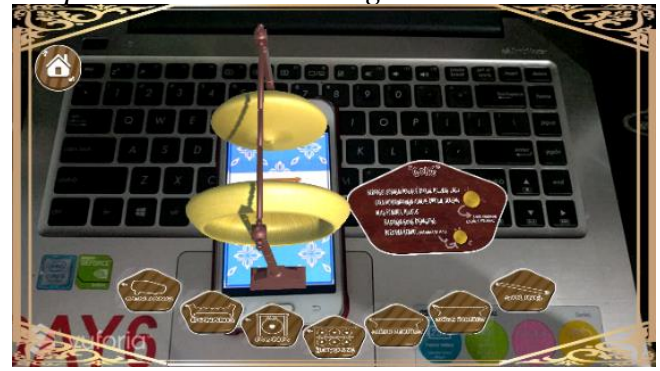

Gambar 23. Hasil tampilan alat musik gong

\section{Pengujian Black Box}

Selanjutnya uji coba dilakukan kepada 4 ponsel yang memiliki spesifikasi yang berbeda, spesifikasi perangkat ponsel 1 ditunjukkan pada tabel IV dan ponsel 2 pada tabel V. Tabel VI menunjukkan informasi tentang keberhasilan dari uji coba aplikasi pada ponsel 1 dan 2, dan tabel VII menunjukkan estimasi waktu fungsi dari aplikasi saat digunakan.

TABEL IV

SPESIFIKASI PONSEL 1

\begin{tabular}{|l|l|}
\hline Versi Android & Android 10 \\
\hline RAM & $3 \mathrm{~GB}$ \\
\hline Memori & $32 \mathrm{~GB}$ \\
\hline Kamera & $13 \mathrm{MP}$ \\
\hline Layar & 5 inch \\
\hline
\end{tabular}

TABEL V

SPESIFIKASI PONSEL 2

\begin{tabular}{|l|l|}
\hline Versi Android & Android 4 (Kitkat) \\
\hline Ram & $768 \mathrm{MB}$ \\
\hline Memori & $4 \mathrm{~GB}$ \\
\hline Kamera & $5 \mathrm{MP}$ \\
\hline Layar & 4.3 inch \\
\hline
\end{tabular}

TABEL VI

PENGUJIAN PADA PONSEL

\begin{tabular}{|c|l|l|}
\hline Pengujian & Ponsel 1 & Ponsel 2 \\
\hline Pemasangan aplikasi & Berhasil & Berhasil \\
\hline Pengoperasian aplikasi & Berhasil & Berhasil \\
\hline $\begin{array}{c}\text { Membuka menu 'cara } \\
\text { memainkan' }\end{array}$ & Berhasil & Berhasil \\
\hline Membuka 'menu tentang' & Berhasil & Berhasil \\
\hline Membuka menu 'Mulai' & Berhasil & Berhasil \\
\hline Memindai marker Kendang & Berhasil & Berhasil \\
\hline Memindai marker Jengglong & Berhasil & Berhasil \\
\hline Memindai marker Gong & Berhasil & Berhasil \\
\hline $\begin{array}{c}\text { Memindai } \text { marker } \text { Suling } \\
\text { Cemindai } \text { marker Saron } \\
\text { Cempres }\end{array}$ & Berhasil & Berhasil \\
\hline $\begin{array}{c}\text { Memindai } \text { marker Saron } \\
\text { Panerus }\end{array}$ & Berhasil & Berhasil \\
\hline $\begin{array}{c}\text { Memindai } \text { marker } \text { Bonang } \\
\text { Merhil }\end{array}$ & Berhasil \\
\hline
\end{tabular}

TABEL VII

ESTIMASI WAKTU APLIKASI

\begin{tabular}{|c|l|l|}
\hline Pengujian & Ponsel 1 & Ponsel 2 \\
\hline Pemasangan aplikasi & 3 menit & 5 menit \\
\hline $\begin{array}{c}\text { Membuka menu 'cara } \\
\text { memainkan' }\end{array}$ & 2 detik & 2 detik \\
\hline Membuka 'menu tentang' & 2 detik & 2 detik \\
\hline Membuka menu 'Mulai' & 5 detik & 8 detik \\
\hline Memindai marker Kendang & 1 detik & 1 detik \\
\hline Memindai marker Jengglong & 1 detik & 1 detik \\
\hline Memindai marker Gong & 1 detik & 1 detik \\
\hline Memindai marker Suling & 1 detik & 1 detik \\
\hline $\begin{array}{c}\text { Memindai marker Saron } \\
\text { Cempres }\end{array}$ & 1 detik & 1 detik \\
\hline $\begin{array}{c}\text { Memindai marker Saron } \\
\text { Panerus }\end{array}$ & 1 detik & 1 detik \\
\hline $\begin{array}{c}\text { Memindai marker } \text { Bonang } \\
\text { Metik }\end{array}$ & 1 detik \\
\hline
\end{tabular}

\section{Pengujian Tampilan Antar Muka}

Tabel VIII memuat informasi tentang nilai kemampuan dari aplikasi yang dibuat, range nilai yang tercantum dari mulai $<75$ yang artinya kurang memuaskan, sampai 100 yang artinya memuaskan. 
TABEL VIII

PENGUJIAN APLIKASI

\begin{tabular}{|c|c|c|c|c|}
\hline No & Pertanyaan & $\mathbf{1}$ & $\mathbf{2}$ & $\mathbf{3}$ \\
\hline 1 & Apakah letak tombol sesuai? & 90 & 87 & 90 \\
\hline 2 & $\begin{array}{c}\text { Apakah tampilannya mudah untuk } \\
\text { difahami? }\end{array}$ & 87 & 85 & 80 \\
\hline 3 & Apakah perpaduan warnanya sesuai? & 80 & 90 & 87 \\
\hline 4 & Apakah tulisan dalam info terbaca? & 90 & 85 & 87 \\
\hline 5 & Apakah alat musik terlihat jelas? & 90 & 86 & 89 \\
\hline 6 & $\begin{array}{c}\text { Apakah suara alat musik terdengar } \\
\text { jelas? }\end{array}$ & 80 & 82 & 82 \\
\hline
\end{tabular}

Tabel VIII menunjukan nilai dari kemampuan aplikasi yang sudah dibuat, 100-90 berarti sempurna, 89-75 sesuai, dan $<75$ berarti perlu perbaikan.

\section{Pengujian Pengguna}

Tabel IX memuat informasi tentang nilai pengujian dari pengguna, untuk range nilai sama seperti tabel VIII yaitu <75 yang artinya kurang memuaskan, sampai 100 yang artinya memuaskan.

\section{TABEL IX}

Pengujian PengGuna

\begin{tabular}{|c|c|c|c|c|}
\hline No & Pertanyaan & $\mathbf{1}$ & $\mathbf{2}$ & $\mathbf{3}$ \\
\hline 1 & Apakah aplikasi ini membantu? & 85 & 90 & 85 \\
\hline 2 & $\begin{array}{c}\text { Apakah aplikasi ini meningkatkan } \\
\text { minat untuk mempelajari alat } \\
\text { musik degung? }\end{array}$ & 85 & 80 & 88 \\
\hline 4 & $\begin{array}{c}\text { Apakah aplikasi ini cocok untuk } \\
\text { semua usia? }\end{array}$ & 80 & 90 & 80 \\
\hline
\end{tabular}

Tabel IX menunjukan nilai dari pengaruh yang dihasilkan saat pengguna sudah menggunakan aplikasi yang sudah dibuat, 100-90 sangat membantu, 89-75 membantu, dan $<75$ tidak berpengaruh.

\section{KESIMPULAN}

Pemanfaatan teknologi yang ada untuk mengenalkan alat musik tradisional adalah salah satu dari banyaknya cara untuk melestarikan budaya Indonesia yang mulai ditinggalkan sedikit demi sedikit, dan salah satu pemanfaatannya adalah aplikasi Augmented Reality Mengenal alat musik tradisional Degung ini. Augmented
Reality ini bisa dibilang adalah teknologi yang sudah cukup dikenal dimasyarakat sehingga diharapkan dengan adanya teknologi ini akan mempermudah orang-orang yang ingin mengenal alat musik degung dan orang yang ingin memperkenalkan alat musik degung. Aplikasi ini akan menampilkan 7 alat musik degung beserta info dan suara dari alat musik tersebut. Dalam pembuatannya yang menggunakan metode MDLC (Multimedia Development life cycle) tentu saja semua jadi terstruktur dan waktu terasa efisien.

\section{DAFTAR PUSTAKA}

S. Surahman, "Dampak Globalisasi Media Terhadap Seni dan Budaya Indonesia,” J. Komun. (Univ. Serang Raya), vol. 2, no. 1, pp. 28-38, 2013.

[2] D. S. Yoga Agustin, "Penurunan Rasa Cinta Budaya Dan Nasionalisme Generasi Muda Akibat Globalisasi," J. Sos. Hum., vol. 4 , no. 2 , pp. 177-185, 2011, doi

10.12962/j24433527.v4i2.632.

[3] H. Sugiarto, "Penerapan Multimedia Development Life Cycle Pada Aplikasi Pengenalan Abjad Dan Angka," IJCIT (Indonesian J. Comput. Inf. Technol., vol. 3, no. 1, pp. 26-31, 2018.

[4] Z. C. Rawis, V. Tulenan, and B. A. Sugiarso, "Penerapan Augmented Reality Berbasis Android Untuk Mengenalkan Pakaian Adat Tountemboan," E-Journal Tek. Inform., vol. 13, no. 1, pp. 30-37, 2018.

[5] T. K. S.Iwan, I.Kodrat, "Pemanfaatan Augmented Reality Untuk Pembelajaran Pengenalan Alat Musik Piano," J. Teknol. dan Sist. Komput., vol. 2, no. 1, p. 9, 2014.

[6] Y. Aprilion, "Implementasi Augmented Reality ( AR ) Pada Fosil Purbakala Di Museum Geologi Bandung" J. Ilm. Komput. dan Inform., vol. 1, no. 1, pp. 1-8, 2014.

[7] P. Haryan and J. Triyono, "Augmented Reality ( AR ) Sebagai Teknologi Interaktif," J. Tek. Ind. Mesin, Elektro, dan Ilmu Komputer(Simetris), vol. 8, no. 2, pp. 807-812, 2017.

[8] A. C. Hanggoro, R. Kridalukmana, and K. T. Martono, "Pembuatan Aplikasi Permainan 'Jakarta Bersih' Berbasis Unity,” J. Teknol. dan Sist. Komput., vol. 3, no. 4, p. 503, 2015 , doi: 10.14710/jtsiskom.3.4.2015.503-511.

[9] D. L. Fithri and D. A. Setiawan, "Analisa Dan Perancangan Game Edukasi Sebagai Motivasi Belajar Untuk Anak Usia Dini," Simetris J. Tek. Mesin, Elektro dan Ilmu Komput., vol. 8, no. 1, pp. 225-230, 2017, doi: 10.24176/simet.v8i1.959.

[10] Yadi, "Mengenal Alat Musik Degung, sebagai Wujud Pelestarian Budaya Nusantara," www.jatinangor.itb.ac.id, 2015. [Online]. Available: https://jatinangor.itb.ac.id/gamelan-sunda-degung/. [Accessed: 15-Jan-2020].

[11] D.Subandi, Julia, D. Gusrayani, "Strategi Pembelajaran Musik Ensemble Melalui Media Gamelan Degung Pada Siswa Kelas V Sekolah Dasar," Jurnal Pena Ilmiah, vol. 2, no. 1, pp. 721-730, 2017, doi: 10.17509/jpi.v2i1.10111. 